\title{
Karakteristik Perubahan Lingkungan Akhir Plistosen - Holosen di Dataran Rendah Aluvial dan Pantai Wilayah Demak, Kudus, Jepara, Pati dan Sekitaranya
}

\section{The Characteristics of Environmental Changes During the Late Pleistocene-Holocene in Alluvial and Beach Area of Demak, Kudus, Jepara, Pati and its Surroundings}

\author{
R.A.T Moechtar ${ }^{1}$, Subiyanto ${ }^{1}$, R.I.H Sulistyawan ${ }^{2}$ \\ ${ }^{1}$ Pusat Survei Geologi, Badan Geologi, Kementerian Energi dan Sumber Daya Mineral \\ Jalan Diponegoro No. 57, Bandung, 40122, Indonesia \\ ${ }^{2}$ Pusat Air Tanah dan Geologi Tata Lingkungan, Badan Geologi, Kementerian Energi dan Sumber Daya Mineral \\ Jalan Diponegoro No. 57, Bandung ,40122, Indonesia \\ e-mail: rioalcanadre@gmail.com \\ Naskah diterima 18 Januari 2019, selesai direvisi 20 April 2021, dan disetujui 30 April 2021
}

\begin{abstract}
ABSTRAK
Wilayah dataran aluvial hingga pantai daerah Demak, Kudus, Jepara, Pati dan sekitarnya ditutupi endapan sedimen Holosen yang terdiri atas kerikil, pasir, lempung, lanau, dan bongkah batuan gunungapi. Penelitian dilakukan dengan analisis sedimentologi dan stratigrafi terhadap 37 pemboran berskala $1: 100$ dengan ketebalan sedimen antara $0,8-18$ meter. Berdasarkan korelasi data hasil pemboran diketahui bahwa sedimen Holosen di wilayah ini dapat dibedakan dalam tiga interval proses pengendapan (IPP A- C). Perubahan sedimen secara vertikal dapat diwakili oleh setiap sub-IPP yang merupakan hasil dari proses eksternal sesuai perubahan iklim, fluktuasi muka laut, tektonik dan aktivitas gunungapi. Dari hasil analisis stratigrafi diketahui bahwa perubahan lingkungan pengendapan pada daerah penelitian berhubungan dengan aktivitas proses eksternal di cekungan ini. Peranan proses eksternal ini diharapkan menjadi variabel dalam perumusan kebijakan pengelolaan lingkungan di wilayah Demak, Kudus, Jepara, Pati, dan sekitarnya.
\end{abstract} Kata kunci: fluktuasi muka air laut, Holosen, lingkungan, tektonik, perubahan iklim

\begin{abstract}
The alluvial plain to the coast of Demak, Kudus, Jepara, Pati and its surroundings is covered with sedimentary Holocene deposits consisting of gravel, sand, clay, silt, and volcanic rock boulders. The study used sedimentology and stratigraphic analysis of 37 drilling points with sediment thickness between 0.8-18 meters. Based on the correlation of drilling results, the Holocene sediments in the area of research can be distinguished in three deposition process (IPP) intervals. Vertically, sediment changes can be represented by each sub-IPP which are the result of external processes according to climate change, sea level fluctuations, tectonics, and volcanic activity. From the results of the stratigraphic analysis, the changes in the depositional environment in the study area are related to external process activities in the basin. The effects of this external process are expected to be a recommendation in the future environmental development in the Demak, Kudus, Jepara, Pati and its surroundings.
\end{abstract}

Keywords: sea level fluctuation, Holocene, environment, tectonic, climate change

\section{PENDAHULUAN}

Selama kurun waktu Kuarter terjadi perubahan lingkungan di banyak tempat, baik secara regional maupun lokal secara bervariasi dari satu tempat ke tempat lainnya (Williams drr., 1993). Williams drr. (1993) menyebutkan bahwa berubahnya lingkungan disebabkan oleh kenaikan suhu, deglasiasi, meningkatnya kekeringan, naik turunnya muka air laut, perubahan arah angin, kontinen, radiasi matahari, dan kandungan debu 
dalam atmosfer. Perlmutter dan Matthews (1989) menyebutkan bahwa sirkulasi iklim yang mendingin dan memanas secara global berhubungan erat dengan berubahnya iklim mengikuti siklus Milankovitch. Daerah pantai utara Jawa (Pati, Kudus, Demak dan sekitarnya) diduga telah mengalami perubahan iklim yang signifkan selama waktu Pleistosen Akhir hingga Holosen. Hal itu telah berdampak kepada proses sedimentasi pada kurun waktu tersebut yang tercermin dari perubahan-perubahan lingkungannya.

Walker dan James (1992) berasumsi bahwa faktor kontrol dinamika pengendapan dalam bentuk turun-naiknya muka laut, tektonik, berubahnya iklim dan evolusi flora-fauna harus menjadi satu kesatuan seumur. Daerah penelitian terletak di Demak dan sekitarnya (Gambar 1). Daerah tersebut memiliki bentang alam yang terbentuk di dataran fluvial hingga pantai yang dipengaruhi aktivitas Gunung Muria. Oleh karena itu, hal tersebut menjadi sangat menarik untuk ditelusuri sehubungan dengan berubahnya lingkungan terkait proses terbentuknya fasies endapan Kuarter berumur akhir Pleistosen hingga Holosen.

Studi karakteristik perubahan lingkungan Pleistosen Akhir-Holosen ini dilakukan untuk memperkuat pemahaman peranan data dasar kebumian dalam proses pembentukan lahan di dataran rendah aluvial hingga pantai di wilayah
Demak, Kudus, Pati dan sekitarnya. Proses ini selanjutnya dapat digunakan sebagai bahan pertimbangan dalam pengelolaan lingkungan dalam jangka menengah maupun jangka panjang.

Dalam Peta Geologi Lembar Kudus Skala 1 : 100.000 (Suwardi dan Wikarno,1992) diketahui bahwa sebagian besar daerah telitian ditutupi oleh alluvium dan kompleks Gunung Muria (Gambar 2). Selain itu, setempat dijumpai formasi batuan Tersier, di antaranya Formasi Ngrayong (Ymn), Formasi Bulu (Tmb) dan Formasi Patiayam (Tpp). Mulyaningsih drr., (2008) menjelaskan bahwa aktivitas Gunung Muria merupakan fluviovulkanik yang terjadi setelah aktivitas Gunung Patiayam. Lebih lanjut, Mulyaningsih drr., (2008) mengemukakan bahwa di wilayah ini telah terjadi aktivitas sedimentasi asal laut setelah aktivitas gunungapi. Mulyono (1996), yang menyusun Peta Geologi Kuarter Lembar Demak, Jawa berdasarkan tipe penampang, menyebutkan bahwa endapan Kuarter berumur Holosen di daerah ini berdasarkan genesa dan lingkungan pengendapannya dibedakan menjadi Supra Litoral (endapan-endapan dataran bajir, sungai tua, dan endapan rawa), Litoral (endapan-endapan pantai, pasang surut, dan lagun) dan Sub Litoral (endapan dekat pantai). Selanjutnya dikatakan bahwa awal proses pengendapan ditandai oleh terbentuknya endapan

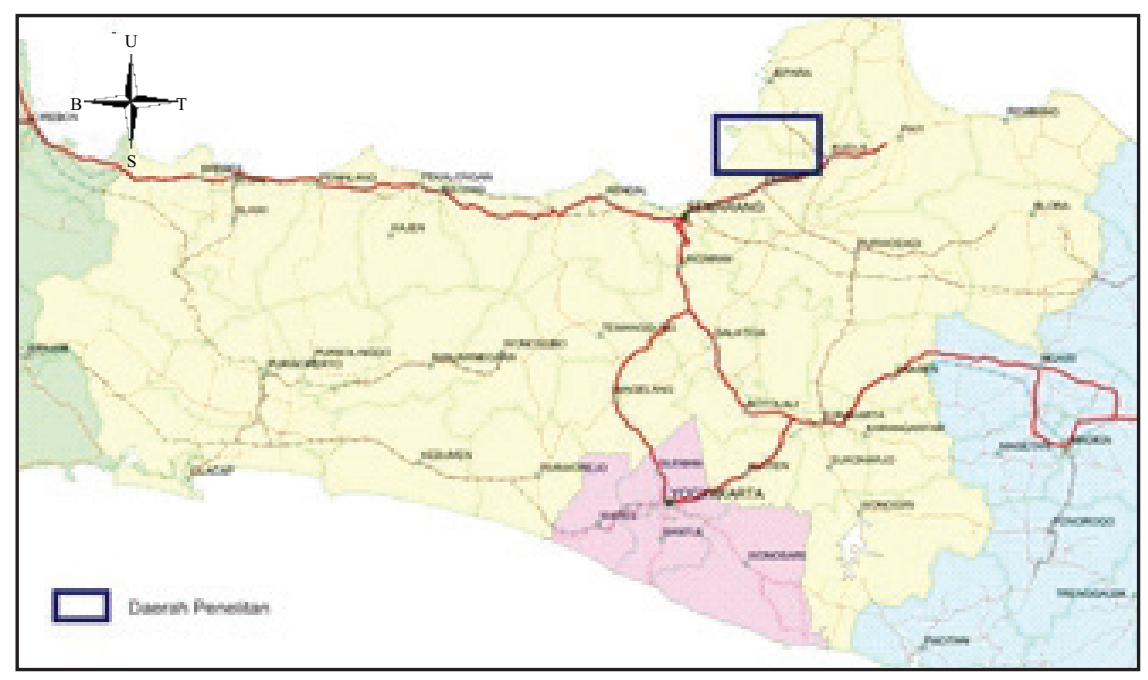

Gambar 1. Lokasi Penelitian Lahan Area 1B Blok J di Lokasi JIIPE, Manyar, Gresik, Jawa Timur. 


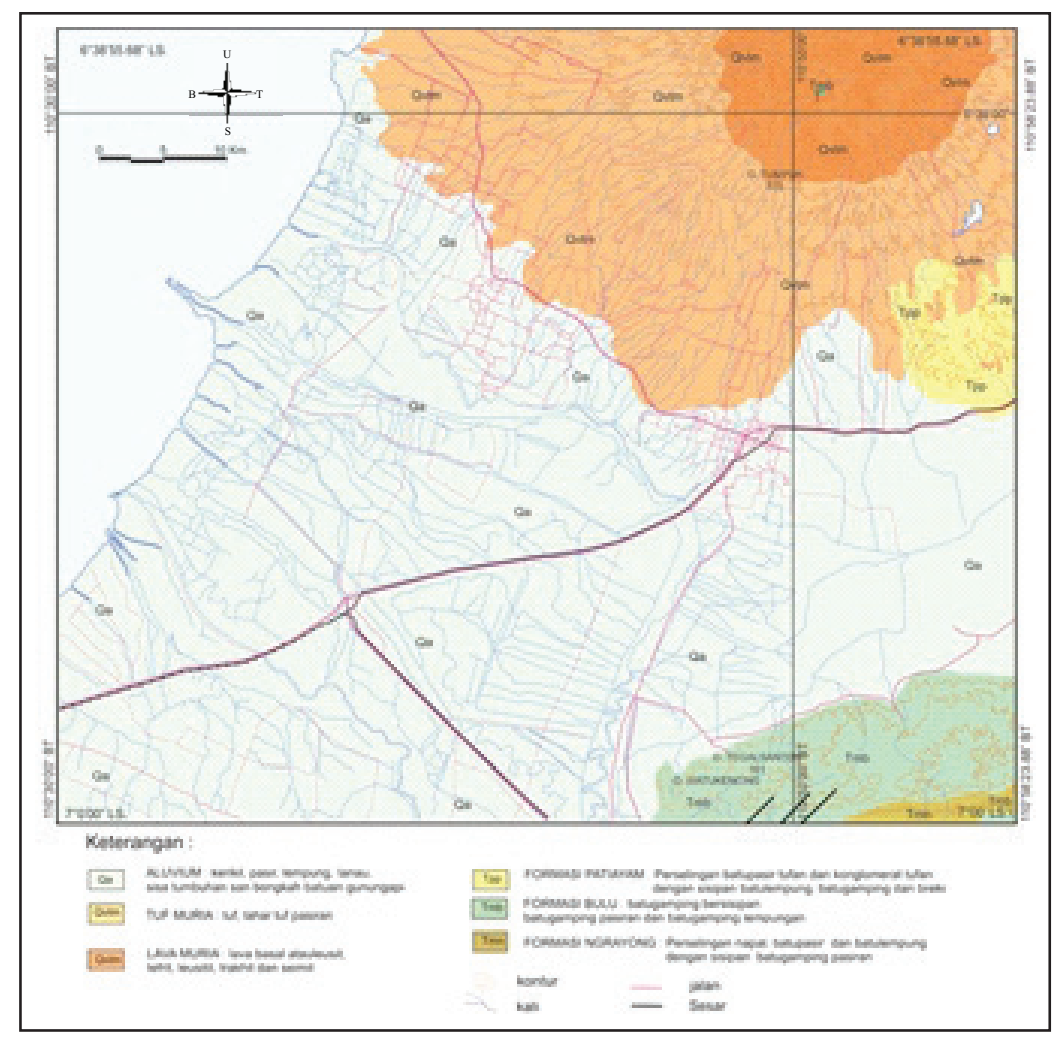

Gambar 2. Peta Geologi Regional daerah Penelitian (Suwardi dan Wikarno, 1992).

dekat pantai kemudian ditutupi oleh endapan pasang surut. Endapan pasang surut terhenti dan ditutupi oleh perkembangan endapan rawa yang kemudia ditutupi oleh endapan dataran banjir yang merupakan interval paling atas.

Lingkungan pengendapan sedimen di daerah Demak, Kudus, Pati dan sekitarnya merupakan lingkungan pengendapan yang dikontrol oleh struktur geologi. Sesar Kaligarang yang membelah Kota Semarang pada arah utara-selatan merupakan sesar yang aktif sejak zaman Tersier hingga Kuarter (Poedjoprajitno drr., 2008). Sesar Kali Garang di Semarang terekam di batuan Kuarter menunjukkan bahwa sesar ini masih aktif atau berpotensi aktif di masa datang (Hidayat, 2013).

\section{METODE PENELITIAN}

Pengambilan data primer dilakukan melalui pengamatan rinci pada sedimen hasil pemboran dangkal menggunakan hand auger sebanyak 37 titik pemboran dengan ketebalan masing-masing antara 0,8-18 meter. Penentuan pemboran ditargetkan pada aluvium pada daerah penelitian dengan membuat lintasan utara-selatan dan barat timur dengan spasi berkisar antara 3-5 kilometer. Interpretasi litologi dan pembagian lingkungan pengendapan dipelajari secara rinci di lapangan terutama perkembangan pembentukan lingkungan pengendapannya secara vertikal. Aspek litologi yang direkam adalah sifat fisik seperti warna, tingkat pelapukan, komposisi, tekstur, perubahan butiran dan sebagainya direkam secara rinci pada log sheet bor tangan.

Setiap titik bor yang sudah dianalisis kemudian dikorelasikan dan dirangkai menjadi beberapa interval susunan pengendapan yang dapat dibedakan antara satu dan yang lainnya yang disebut sebagai interval proses pengendapan (IPP) (Gambar 3). Rangkaian susunan interval sedimen tersebut mencerminkan karakteristik perubahan lingkungan yang dipengaruhi sirkulasi iklim terkait fluktuasi muka laut dan tektonik (Gambar 4). 


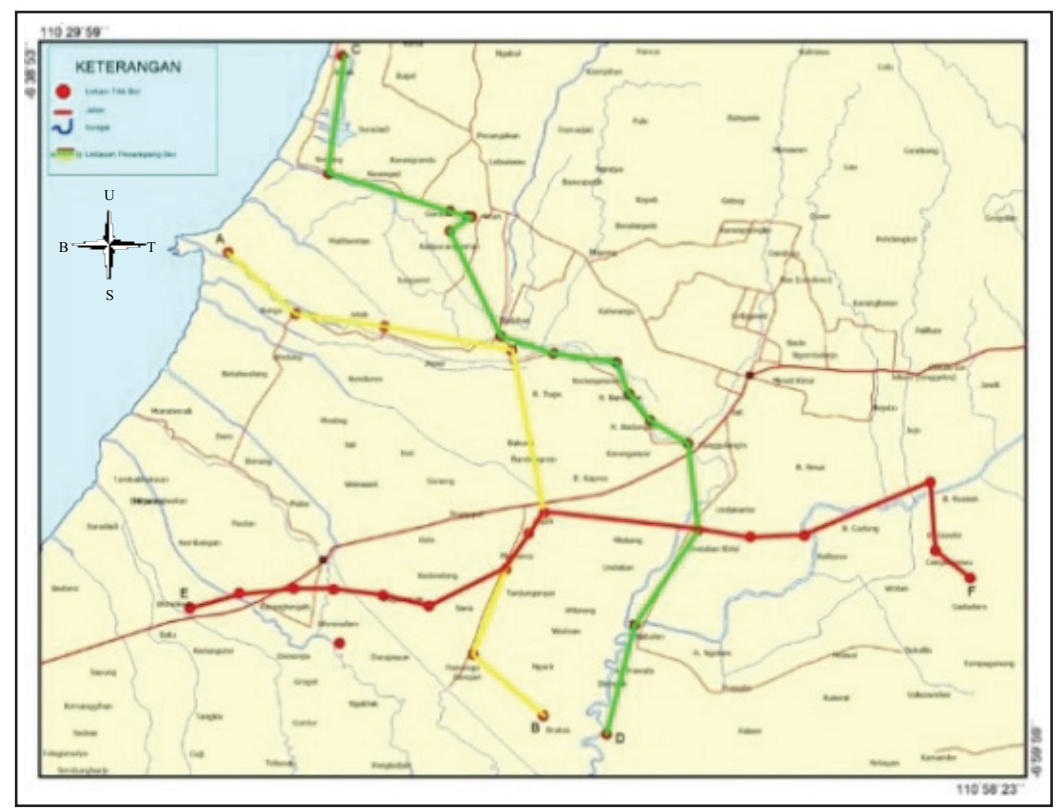

Gambar 3. Peta Lokasi Bor dan Lintasan Korelasi Lintasan Stratigrafi.

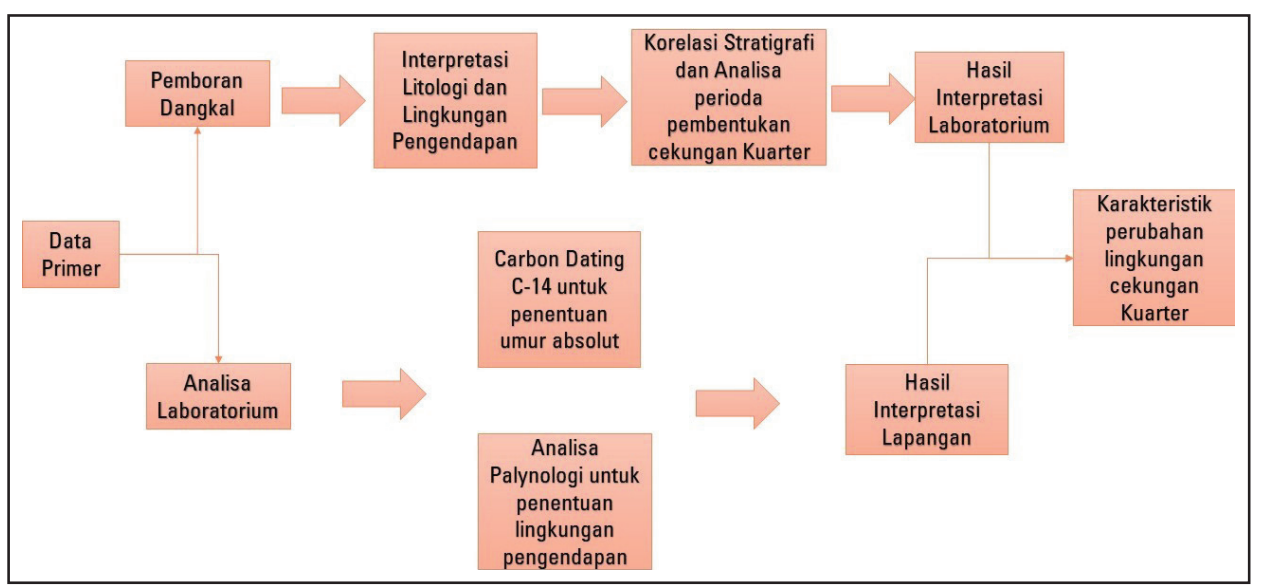

Gambar 4. Bagan Metodologi Penelitian.

Analisis laboratorium yang digunakan pada penelitian ini adalah Carbon Dating C-14 pada lapisan endapan rawa. Analisis radiokarbon C-14 dilakukan untuk mengetahui umur absolut pada lapisan tersebut.

\section{HASIL DAN PEMBAHASAN}

Berdasarkan data lapangan, sedimen Holosen hasil pemboran merupakan litologi yang belum terkonsolidasikan dan terdiri atas perselingan antara lanau dan pasir, perselingan antara lanau dan lempung, pasir koral, gambut lempungan, pasir, perselingan lempung dan pasir, lempung, tufa, dan koral. Sepintas susunan litologi tersebut kompleks, tetapi klastik halus yang berasal dari sedimen laut cukup menonjol. Setiap titik bor dari 37 lokasi telah dilakukan deskripsi litologi secara rinci hingga ditafsirkan fasies dan lingkungan pengendapannya (Gambar 5).

Berdasarkan hasil analisis sedimentologi, litologi sedimen Holosen dibedakan menjadi fraksi endapan klastik berbutir kasar seperti pasir dan halus seperti lempung, lanau, dan lempung bergambut. Selanjutnya litologi sedimen Holosen bawah permukaan dibedakan menjadi fasies- 
Karakteristik Perubahan Lingkungan Akhir Plistosen - Holosen di Dataran Rendah Aluvial dan Pantai Wilayah Demak, Kudus, Jepara, Pati dan Sekitaranya

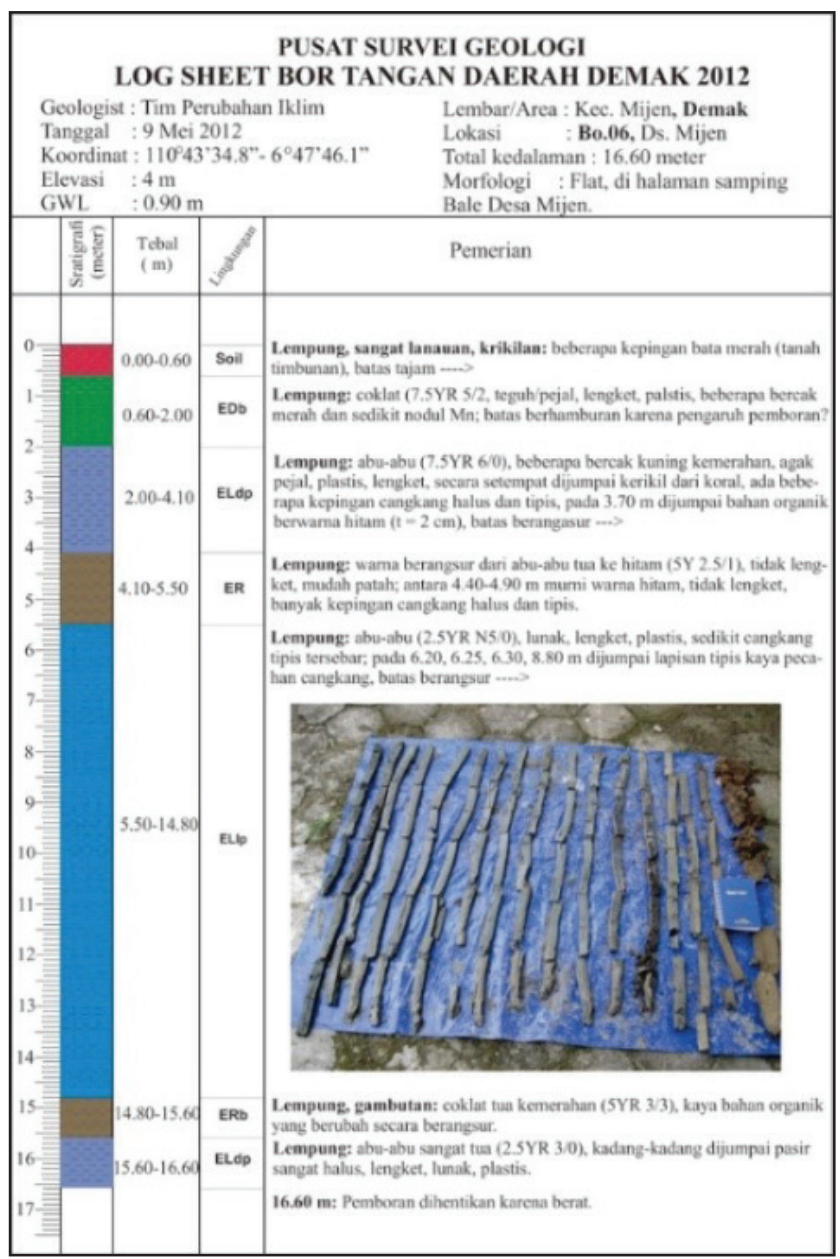

Gambar 5. Pemerian dan penafsiran lingkungan pengendapan pada titik bor BO.6.

fasies yang berasal dari sistem fluvial, klastika linear (linear clastic sediments), rawa bakau (mars/mangrove), dan rawa (swamp). Selanjutnya sistem fluvial dibedakan menjadi endapanendapan alur sungai (Eas), dataran banjir (Edb), dan Dataran banjir yang dipengaruhi pasang surut (Edbps). Sebaliknya, fasies klastika linear dibedakan menjadi endapan-endapan pantai (Ep), laut dekat pantai (Eldp), dan laut lepas pantai (Ellp) (Gambar 6). Fasies endapan rawa (ER) temasuk endapan rawa yang dipengaruhi pasang surut (Erps) juga dijumpai. Selain itu, di beberapa tempat ditemukan endapan rawa bakau.

Di titik bor dengan kode BO 8 di desa Kedunwaru Kidul dijumpai material yang tak terpisahkan berupa endapan debris atau rombakan (Ed) yaitu percampuran material rawa, laut, dan sungai. Akhirnya, material hasil erupsi berupa tufa, la- har dan tufa pasiran cenderung diklasifikasikan sebagai hasil erupsi gunungapi sebagai tufa $\mathrm{Mu}-$ ria (Qutm). Ringkasan lingkungan pengendapan dan penciri litologi dapat dilihat pada Tabel 1 .

Data primer hasil pemboran yang berjumlah 37 dilakukan deskripsi litologi secara rinci hingga ditafsirkan fasies dan lingkungan pengendapannya (Gambar 6). Setelah itu, titik-titik pemboran dirangkai menjadi 3 rangkaian stratigrafi A-B, C-D, dan E-F.

Rangkaian stratigrafi A-B sekitar alur kali Wulan dari arah barat laut - tenggara dapat menjelaskan bagaimana kondisi dari perkembangan proses berubahnya lingkungan yang terjadi mulai dari desa Menco hingga Desa Cangkringmulya dari titik lokasi bor Bo.1 hingga lokasi bor Bo.21 (Gambar 7). Adapun kondisi perubahan lingkungan terbagi menjadi 3 interval. 


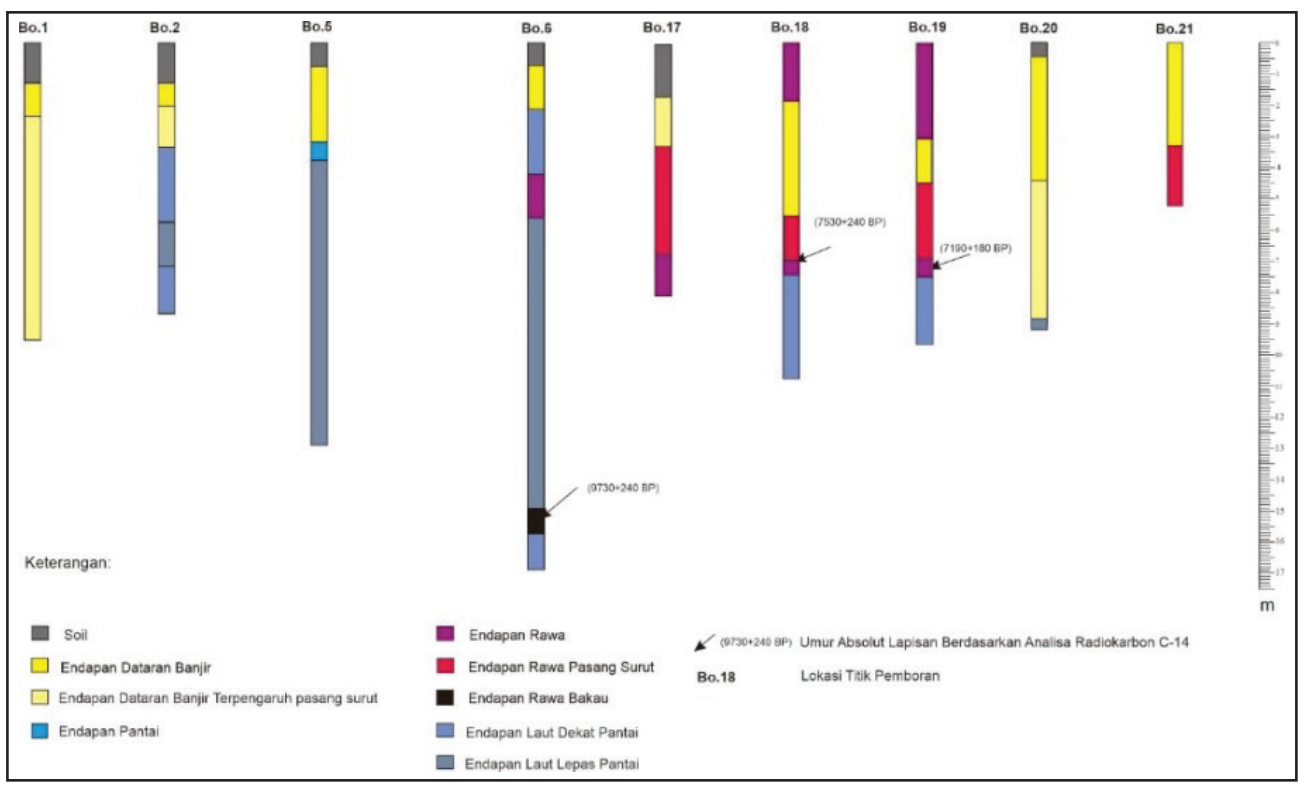

Gambar 6. Lingkungan Pengendapan yang Ditemukan pada Beberapa Titik Pemboran yang Kemudian Dirangkaiakan Stratigrafinya pada Rangkaian A-B dan 3 Hasil Analisis Radiocarbon C-14.

Gambar 6. Lingkungan Pengendapan dan Kenampakannya yang terdapat pada daerah penelitian

\begin{tabular}{|c|c|c|}
\hline No & $\begin{array}{l}\text { Lingkungan } \\
\text { Pengendapan }\end{array}$ & Kenampakan \\
\hline 1 & $\begin{array}{l}\text { Endapan alur sungai } \\
\text { (Eas) }\end{array}$ & $\begin{array}{l}\text { Endapan ini terdiri atas pasir halus kadang-kadang berukuran medium dan kerikilan berukuran } 3-5 \\
\text { mm berwarna coklat kekuningan, membulat tanggung hingga menyudut, terpilah sedang, terkadang } \\
\text { mengandung unsur organic,sisa tumbuhan dan lapisan tipis humus. Endapan ini tersusun dari butiran } \\
\text { kuarsa, pecahan batuan andesit dan feldspar sera mineral hitam lainnya yang tersebar sangat sedikit } \\
\text { meski pemboran dilakukan dekat alur sungai. }\end{array}$ \\
\hline 2 & $\begin{array}{l}\text { Endapan dataran } \\
\text { banjir (Edb) }\end{array}$ & $\begin{array}{l}\text { Litologinya tersusun dari lempung kadang kadang pasiran dan lanuan dengan warna coklat keputihan, } \\
\text { putih kekuningan hingga abu-abu. Warna umumnya dipengaruhi oleh tingkat pelapukan dan kandungan } \\
\text { humusnya serta konkresi besi dan berbecak kuning kemerahan. Padat dan sulit ditembus dengan tingkat } \\
\text { kekenyalan tinggi, dan mengandung sisa-sisa tumbuhan yang sebarannya tidak merata ke arah atasnya } \\
\text { ditandai oleh proses pelaupukan dan menyusutnya lingkungan fasies ini. }\end{array}$ \\
\hline 3 & $\begin{array}{l}\text { Endapan dataran } \\
\text { banjir dipengaruhi } \\
\text { pasang surut (Edbps) }\end{array}$ & $\begin{array}{l}\text { Lempung, lanau pasiran, berwarna coklat abu-abu hingga abu-abu kecoklatan, padat dan mengandung } \\
\text { sisa tumbuhan sbeagai pertanda material hasil pelimpahan alur sungai. Sering ditemukan lapisan tipis } \\
\text { sedimen klastik bebearapa mm berupa lempung lanauan berwarna abu-abu kehijauan. Ditafsirkan } \\
\text { sebagai endapan dataran banjir yang dipengaruhi oleh pasang surut laut. }\end{array}$ \\
\hline 4 & Endapan pantai (EP) & $\begin{array}{l}\text { Litologinya tersusun dari pasir halus hingga menengah dan butirannya seragam, berwarna abu-abu } \\
\text { kehijauan hingga abu - abu muda, terpilah sedang, mengandung moluska dan material organik serta sisa } \\
\text { tumbuhan. Interval pasir ke arah bawah semakin gelap bewarna hijau dan kaya kandungan moluska tapi } \\
\text { miskin kandungan organik. Endapan ini tersebar dibeberapa tempat atau dengan kata lain sebarannya } \\
\text { tidak teratur dan tidak linier. }\end{array}$ \\
\hline 5 & $\begin{array}{l}\text { Endapan laut lepas } \\
\text { pantai (Ellp) }\end{array}$ & $\begin{array}{l}\text { Ciri endapan ini berupa lempung berwarna hijau hingga abu-abu tua kehijauan, lunak, plastisitas tinggi, } \\
\text { mengandung foraminifera dan moluska, bersisipan pasir halus, tidak mengandung material organik } \\
\text { ataupun sisa tumbuhan. Pada interval tertentu disisipi lapisan lempung dengan pecahan yang berlimpah } \\
\text { setebal kurang lebih } 10 \mathrm{~cm} \text { secara berulang. Ketebalan lapisan tidak merata sehingga ditafsirkan bahwa } \\
\text { lapisan demikian memilki arah arus berbeda dari waktu ke waktu. Perbedaan yang mencolok dengan } \\
\text { Eldp adalah dominannya lempung berwarna gelap tanpa kandungan material yang berasal dari daratan. }\end{array}$ \\
\hline 6 & Endapan Rawa (ER) & $\begin{array}{l}\text { Terdiri atas lempung berwarna hitam, lunak dan sedikit mengandung pasir. Lempung organik dengan } \\
\text { sisa dan akar tanaman sering dijumpai. Selain itu, pada lapisan mengandung moluska air tawar, dan } \\
\text { lapisan gambut. Tidak ada tanda-tanda fasies ini berhubungan dengan fasies fluvial sehingga warna } \\
\text { dari lempung relatif homogen. Lapisan gambut tersebar tidak merata dan fasies rawa ini cenderung } \\
\text { terbentuk di walayah genangan yang sifatnya tidak musiman. }\end{array}$ \\
\hline 7 & $\begin{array}{l}\text { Endapan rawa } \\
\text { dipengaruhi pasang } \\
\text { surut (Erps) }\end{array}$ & $\begin{array}{l}\text { Litologi endapan ini terbentuk di daerah pasang surut yang dicirikan oleh pasir halus hingga lanau } \\
\text { lempungan berwarna hitam kehijauan hingga abu-abu kehitaman kadang kadang mengandung sisa } \\
\text { tumbuhan dan lapisan lempung berwarna hijau dan banyak mengandung material organik dengan } \\
\text { sedikit kandungan moluska berupa pecahan-pecahan kerang. Jenis fasies ini menempati beberapa } \\
\text { interval yang mengindikasikan pengaruh turun naiknya muka laut ditempat tersebut berlangsung. }\end{array}$ \\
\hline 8 & $\begin{array}{l}\text { Endapan rawa bakau } \\
\text { (Erb) }\end{array}$ & $\begin{array}{l}\text { Litologi endapan ini terdiri atas lempung berwarna hitam, sarat mengandung potongan tumbuhan } \\
\text { bakau pada bagian bawahnya lalu berangsur menjadi lempung berwarna abu-abu kehijauan. Tidak } \\
\text { mengandung material organik dan moluska serta sifatnya lunak. }\end{array}$ \\
\hline
\end{tabular}




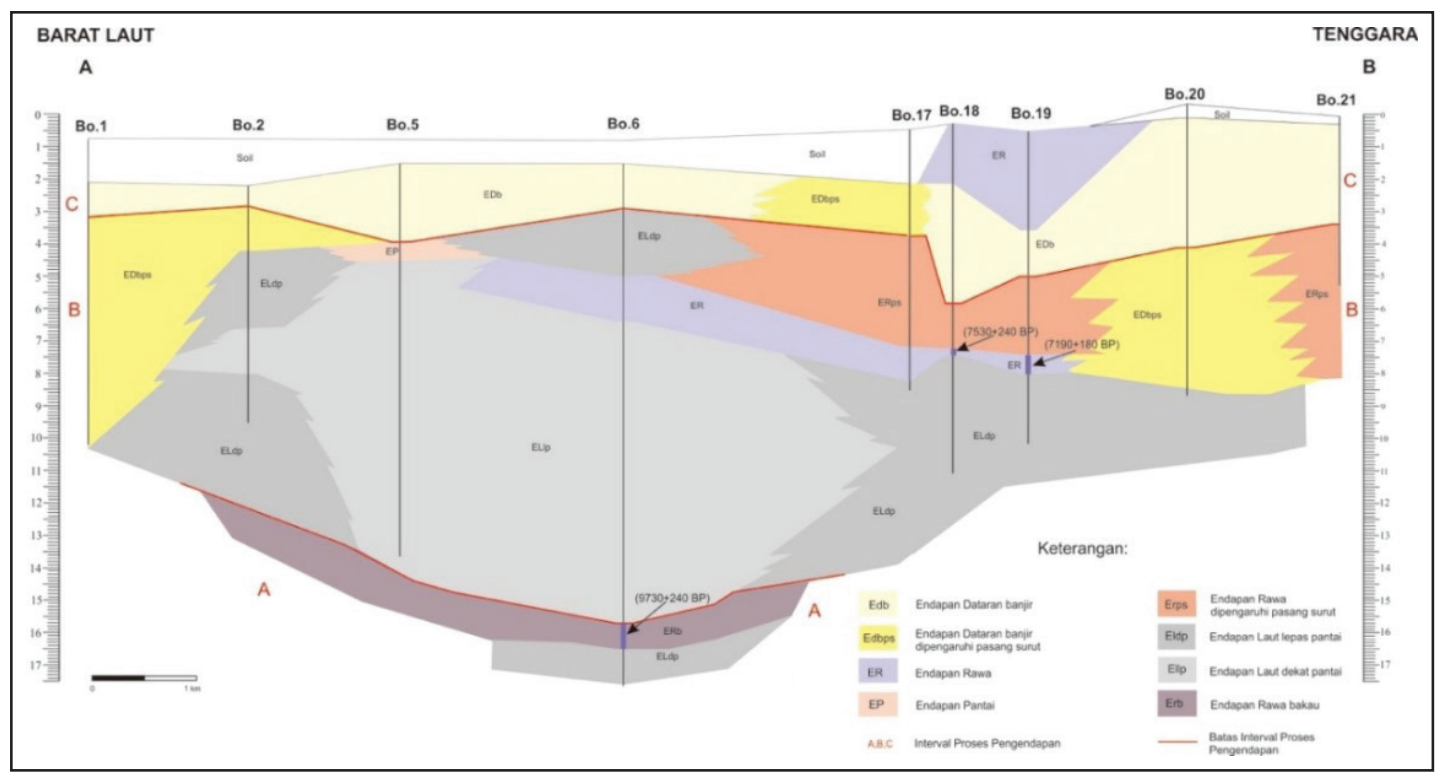

Gambar 7. Rangkaian Stratigrafi sekitar alur Sungai Wulan dan sekitaranya (Bo 1 - Bo21).

Interval proses pengendapan A(IPP-A) diawali dengan endapan rawa bakau menutupi endapan laut dekat pantai pada umur 9780240 mencirikan susut laut berlangsung yang kejadiannya secara berangsur. Ke arah atas IPP A ditutupi oleh endapan laut lepas pantai dan endapan laut dekat pantai sebagai IPP B. Tatanan stratigrafi demikian menjadi indikasi bahwa peralihan IPP A dan IPP B merupakan siklus naiknya muka laut tetapi diselingi oleh turunnya muka laut di bagian atas IPP-A.

Interval proses pengendapan B (IPP-B) merupakan sistem cekungan kecil yang ideal terlihat pada IPP-B yang pada bagian tengahnya merupakan sumbu cekungan. Ke arah baratlaut dan tenggaranya merupakan paparan atau bagian pinggir cekungan sehingga ke arah tenggara mendekati pantai sekarang, muka laut turun terlebih dahulu menghasilkan endapan rawa dan sistem fluvial. Secara umum IPP-B diasumsikan sebagai muka laut turun meski pada beberapa tempat naik secara lokal. Namun, dasar cekungan ketika itu terjadi penurunan yang terbukti dengan ditemukannya endapan rawa yang ditutupi oleh endapan laut dekat pantai. Hal ini mengindikasikan bahwa kondisi dasar cekungan mengalami naik turun. Endapan rawa yang terbentuk di bagian atas IPP B berumur $7630 \pm 240$ dan $7190 \pm 180$.
Interval proses pengendapan C (IPP C) dicirikan dengan rangkaian stratigrafi cukup sederhana dengan ditandai oleh berkembangnya lingkungan darat seiring dengan muka laut turun hingga ke posisi sekarang. Dominannya lingkungan fluvial yang menghasilkan pelimpahan alur sungai merupakan kejadian yang umum terjadi di daerah dataran aluvium dekat pantai menuju dataran rendah pantai meski pada lokasi tertentu pengaruh pasang surut masih ada. Selanjutnya, alur sungai semakin menyusut dan diikuti perkembangan dataran rawa dan proses terbentuknya soil.

Pada rangakaian stratigrafi C-D sekitar alur kali Serang dan sekitarnya dari titik bor Bo. 31 hingga Bo. 13 terbagi menjadi 3 interval.

Interval proses pengendapan A (IPP A) merupakan peralihan fasies baik secara lateral ataupun vertikal berlangsung secara berangsur dan tidak memperlihatikan bidang permukaan erosional secara tegas. Peralihan fasies yang dimaksud yaitu terjadinya genang laut setelah terbentuknya endapan dataran banjir dan endapan rawa pasang surut. Pada titik bor dengan kode Bo. 31 dijumpai fasies erupsi gunungapi formasi Qvtm yang lapuk berwarna merah kecoklatan. Fasies ini diduga sebagai fasies alas yang ditutupi endapan sedimen muda. Hubungan kedua fasies ini ber- 
beda, di mana fasies gunungapi ini membentuk paleosoil yang berhubungan dengan pelapukan fisika. Pelapukan fisika tersebut menandakan kondisi iklim kering atau minimum. Sedangkan pelapukan sedimen klastik cenderung di bawah pengaruh iklim optimum yang terbukti dengan ditemukannya pelapukan endapan dataran banjir berwarna gelap yang mengindikasikan terjadinya pelapukan kimia. Oleh karena itu, peristiwa erupsi terjadi di kala kondisi kering menuju lembab (humid) yang membentuk sedimen klastik pada IPP A. Selain itu, karakter fasies endapan dataran banjir berupa lempung abu-abu kecoklatan, lengket dan mengandung sisa tumbuhan di bawah pengaruh energi aliran semakin tinggi yang ke arah bawah secara berangsur warna litologinya semakin terang yaitu coklat kekuningan yang menunjukkan kondisi iklim semakin kering. Sebaliknya lingkungan rawa ke arah atas menunjukkan volume air semakin besar sehingga ditafsirkan terbentuknya interval periode pengendapan A pada kondisi iklim minimum menuju optimum. Juga, muka laut naik sebagai indikator berubahnya iklim ke lembab atau basah yang setara dengan naiknya muka air laut.

Interval proses pengendapan B (IPP-B) dicirikan dengan genang laut yang diikuti susut laut merupakan karakter IPP-B dan berubahnya berbagai lingkungan secara cepat ditunjukkan pada interval atasnya. Di bagian utara perubahan lingkungan secara umum berlangsung berangsur dengan ditunjukkan oleh perubahan endapan laut lepas pantai ke endapan laut dekat pantai hingga endapan dataran banjir pasang surut. Ketika itu, posisi muka laut maksimum hingga kembali turun. Kondisi muka laut turun ditunjukkan oleh terbentuknya fasies linier klastik yang beralih ke lingkungan rawa di selatan dan dataran banjir. Secara vertikal berubahnya muka laut terjadi secara tidak teratur selama muka laut turun yaitu di kala endapan rawa ditutupi endapan laut dekat pantai. Semakin ke arah selatan, turunnya muka laut relatif cepat, terbukti dengan dominannya endapan laut dekat pantai yang diselingi endapan rawa. Interval ini semakin rumit ketika terbentuknya endapan alur sungai yang ditutupi endapan pantai dan endapan laut dekat pantai sebelum membentuk endapan dataran banjir. Secara umum, IPP-B ditandai muka laut turun tetapi perubahan lingkungan relatif cepat di bagian atas interval.

Interval proses pengendapan C (IPP-C) merupakan sistem fluvial yang sebagian besar diwakili oleh endapan dataran banjir merupakan peristiwa dominan pada IPP-C. Secara umum, muka laut turun hingga ke posisi sekarang yang pada akhirnya membentuk bentang alam dataran aluvium yang pasokan materialnya berasal dari sungai. Material gunungapi yang menutupi endapan laut dekat pantai yang dicirikan oleh bor Bo. 27 - Bo. 29 memberi indikasi bahwa telah terjadi kegiatan erupsi gunungapi.

Rangkaian stratigrafi E-F berarah B-T yang memotong alur sungai pada korelasi titik bor Bo. 31 hingga Bo. 14 yang terbagi menjadi 3 interval (Gambar. 9).

Interval proses pengendapan A (IPP A) merupakan endapan laut lepas pantai sangat dominan terbentuk yang memungkinan bertindak sebagai pusat cekungan ketika itu. Pada bagian atas ditandai oleh lapisan berwarna gelap yaitu hijau kebiruan yang beralih ke abu-abu kehijauan dan semakin ke arah bawah fasies ini diwakili klastika yang lebih kasar yaitu lanau dan pasir halus sebagai penciri maksimum muka laut berada di bagian atas interval atau dengan kata lain genang laut identik dengan pembentukan IPP A.

Interval proses pengendapan B (IPP B) diawali susut laut adalah ciri terbentuknya IPP B dan ke arah timur cenderung menuju pinggir cekungan dengan diendapkannya endapan dataran banjir pasang surut. Di bagian atas tengah interval memperlihatkan muka air laut turun secara cepat dibanding di sebelah baratnya yang terendapkan endapan rawa dan endapan rawa pasang surut, sehingga pada bagian barat diduga merupakan sumbu cekungan. Selama pembentukan fasies-fasies endapan pada ini interval ini tidak memperlihatkan tanda tanda berubahnya lingkungan secara signifikan sehingga proses 
Karakteristik Perubahan Lingkungan Akhir Plistosen - Holosen di Dataran Rendah Aluvial dan Pantai Wilayah Demak, Kudus, Jepara, Pati dan Sekitaranya

sedimentasi berjalan secara normal. Muka laut turun di bawah pengaruh iklim optimim menuju minimum bersamaan dengan terjadinya susut laut.

Interval proses pengendapan C (IPP C) diwakili terbentuknya endapan rawa secara berangsung beralih ke lingkungan fluvial sebagai penciri IPP $\mathrm{C}$ kecuali di bagian timur di mana lingkungannya beralih menjadi rawa. Tidak terlihat berubahnya lingkungan secara signifikan dan beralihnya endapan dataran banjir yang dipegnaruhi oleh pasang surut adalah efek turun naiknnya muka laut secara lokal. Sebaliknya lingkungan rawa yang berkembang sebagai peralihan dari sistem fluvial dikarenakan berkurangnya volume air yang mengakibatkan aktivitas alur sungai menurun. Kondisi terbentuknya IPP C cenderung di bawah pengaruh muka laut yang semakin turun dalam suasana iklim minimum.

Berdasarkan ketiga rangkaian stratigrafi tersebut, terjadi perubahan fasies pengendapan secara lateral dan gejala ini sangat terkait terhadap berubahnya lingkungan. Sebaliknya secara vertikal perubahan itu berlangsung sehingga lingkungan mengalami pergeseran. Perubahan evolusi secara vertikal ini relatif rumit.
Turun naiknya muka laut berlangsung cepat sehingga lingkungan transisi mengalami perubahan yang cepat juga. Sebaliknya, alur sungai tidak berkembang secara baik akibat kecepatan naiknya muka laut tersebut. Turun naiknya muka laut yang rumit dan kompleks tersebut berdampak pada siklus fluktuasi muka laut secara global tidak terbentuk yang digantikan oleh siklus perubahan lingkungan secara lokal.

Perubahan lingkunan IPP-A terkait lingkungan darat dan erupsi gunungapi yang dicirikan oleh terbentuknya lingkungan laut secara dominan (Gambar 8) sedangkan di tempat lain diselingi oleh lingkungan rawa yang dialasi oleh lingkungan laut (Gambar 7) cenderung mengindikasikan perubahan lingkungan demikian menjadi ekstrem. Lingkungan laut semakin menyusut pada IPP B dan dicirikan berkembangnya lingkungan fluvial pada IPP-C.

Karena didasari dinamika proses pengendapan maka perubahan lingkungan dapat dijelaskan IPP A Merupakan lingkungan laut lepas pantai di selatan (Gambar 7) yang semakin ke arah utara (Gambar 8) laut semakin dangkal. Semakin ke arah utara ditutupi oleh lingkungan rawa. Karakter lingkungan yang terbentuk

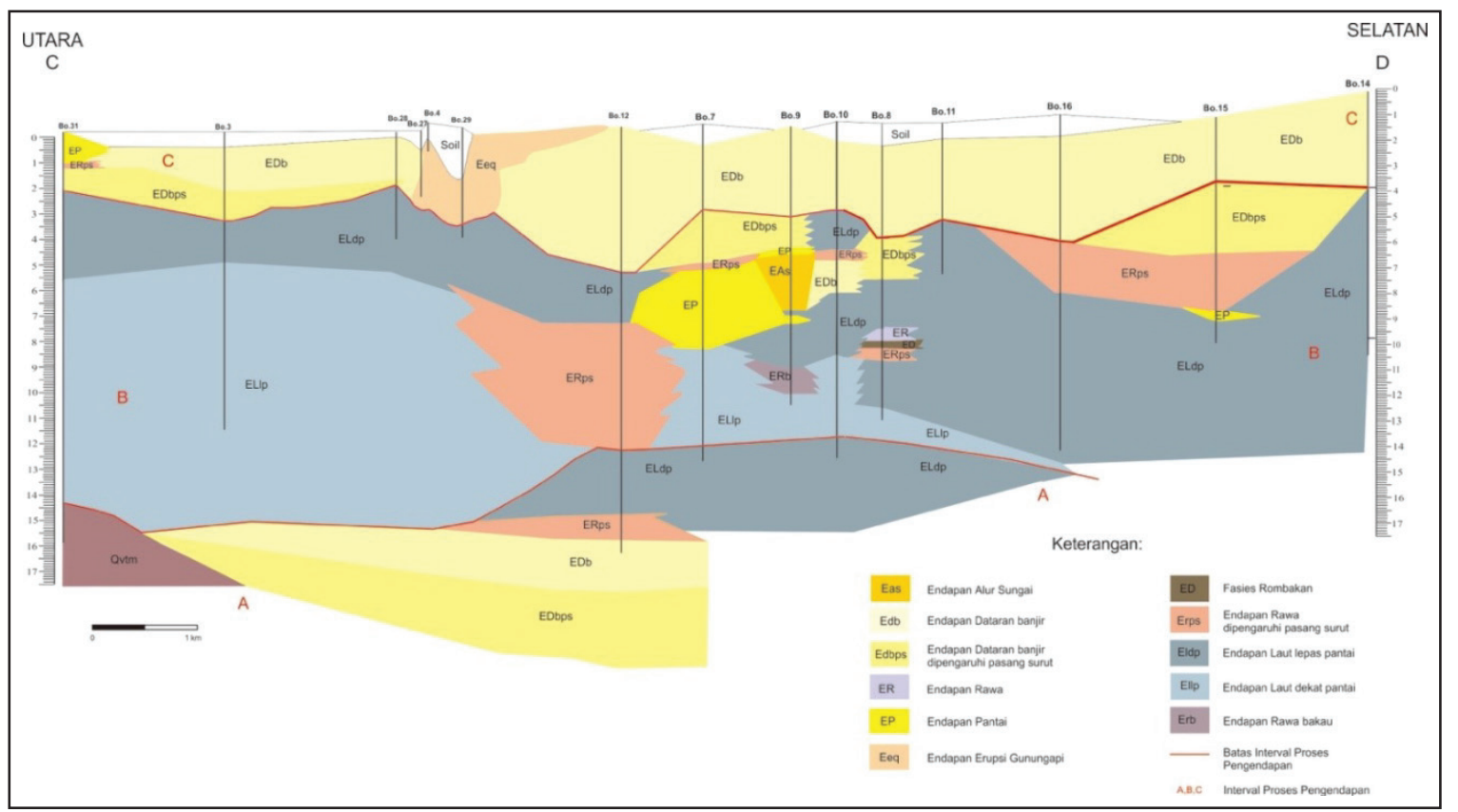

Gambar 8. Rangkaian Stratigrafi sekitar alur sungai Serang dan sekitarnya (Bo 31 - Bo.14). 
tersebut di antaranya adalah awal terbentuknya lingkungan merupakan lingkungan darat yang ditutupi oleh hasil kegiatan erupsi gunungapi. Pelapukan kondisi tersebut diasosiakan sebagai proses kimia yang cenderung dominan dibanding proses fisika di mana warna pelapukannya coklat kemerahan. Berkembangnya lingkungan fluvial dan rawa yang dipengaruhi pasang surut sebagai pertanda tingkat kelembapan semakin meningkat akibat pengaruh muka laut naik. Akhir pembentukan lingkungan IPP-A ditandai oleh naiknya muka laut dengan pusat cekungan berada di selatan. Ke arah utara lingkungan rawa berkembang sehingga perubahan tersebut sebagai pertanda alas cekungan bergerak naik sehingga muka laut turun.

Secara umum perubahan lingkungan diawali oleh kegiatan erupsi Gunung Muria pada kondisi iklim minimum menuju optimum. Kondisi iklim semakin lembab menghasilkan proses rawa yang diikuti oleh naiknya muka laut. Muka laut semakin tinggi namum proses pengangkatan terjadi di Utara. Oleh karena itu, secara regional naiknya muka laut tertahan akibat alas cekungan naik.

Perubahan lingkungan selama IPP-B rumit baik secara lateral maupun vertikal. Secara umum kondisi lingkungan ketika itu di bawah pengaruh susut laut dan dapat dijelaskan yaitu di utara terbentuk rawa yang sebelumnya merupakan lingkungan laut terbuka, sedangkan di barat dan timur posisi laut dekat dengan pantai. Muka laut naik akibat alas cekungan turun sehingga cekungan semakin dalam (Gambar 8 dan Gambar 9). Akhir terbentuknya IPP B, muka laut semakin turun (Gambar 7) membentuk rawa dan pantai. Di bagian tengah perubahan lingkungan relatif cepat dan rumit dan kemungkinan di tempat tersebut dipengaruhi oleh turun naiknya alas cekungan. Ke arah selatan, muka laut susut secara konstan yang mengindikasikan daerah tersebut relatif stabil. Bagian atas IPP-B ditandai oleh lingkungan di mana muka laut turun sehingga sebagian besar wilayah penelitian menjadi daratan, tetapi di beberapa tempat terjadi perubahan lingkungan secara signifikan.

Uraian di atas memberi gambaran bahwa secara regional proses penurunan yang terjadi berhubungan dengan proses pengangkatan sebelumnya. Pusat sumbu cekungan tersebut diduga berada di bagian tengah penampang A-B dan C-D (Gambar 7 dan Gambar 8). Perubahan lingkungan yang terjadi berhubungan dengan kecepatan muka laut naik secara global dan kecepatan naik turunnya cekungan secara regional. Akhir pembentukan IPP B terkait dengan bergeraknya

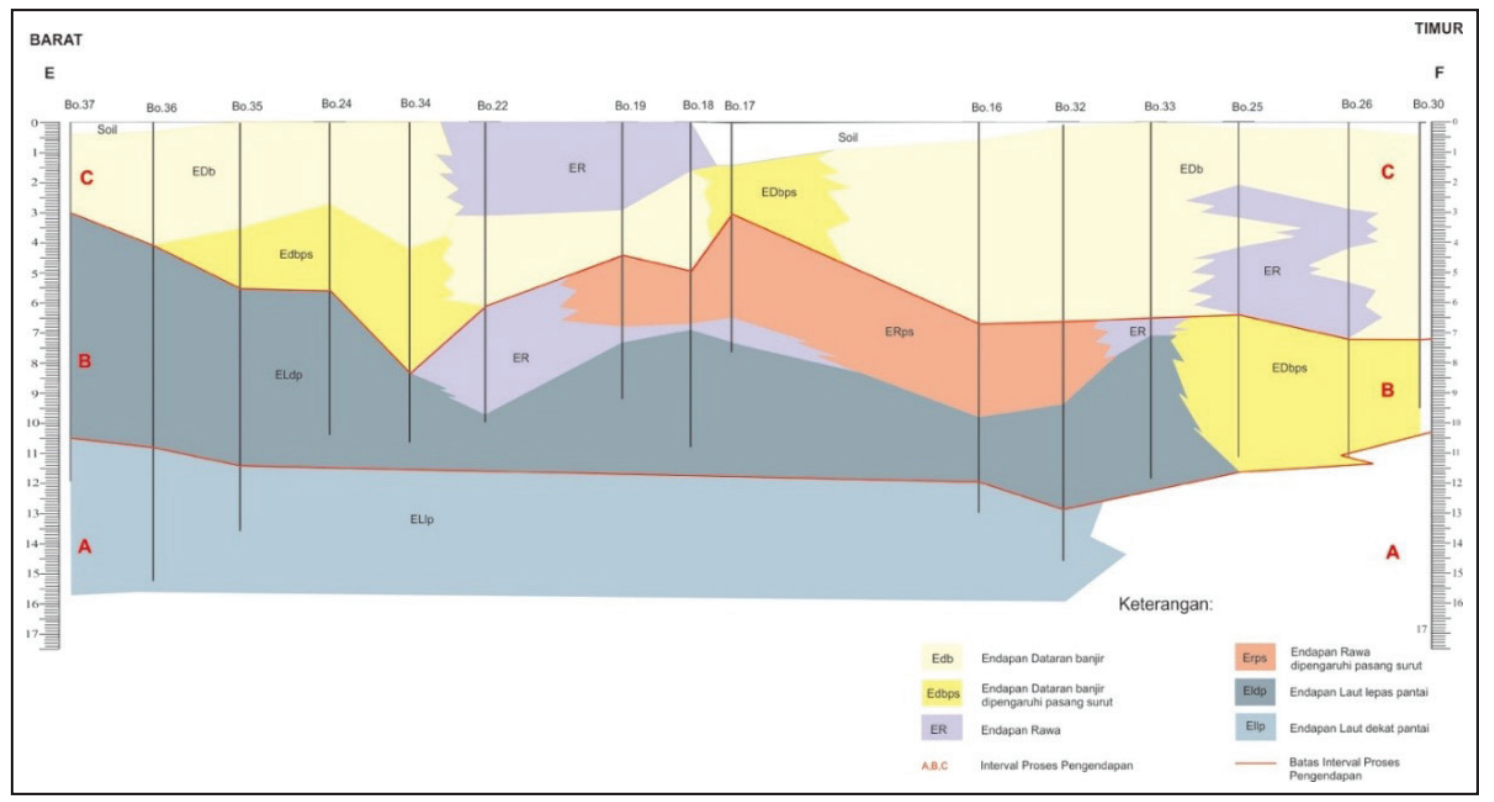

Gambar 8. Rangkaian Stratigrafi berarah Barat - Timur yang memotong alur - alur sungai (Bo 37 - Bo 30). 
Karakteristik Perubahan Lingkungan Akhir Plistosen - Holosen di Dataran Rendah Aluvial dan Pantai Wilayah Demak, Kudus, Jepara, Pati dan Sekitaranya

alas cekungan secara lokal, sebaliknya muka laut semakin turun tetapi di utara muka laut kembali naik akibat alas cekungan ditempat tersebut bergerak turun.

Sedangkan pada IPP-C, muka laut semakin turun dan lingkungan darat semakin dominan. Di utara tidak memperlihatkan berubahnya lingkungan secara signifikan dan lingkungan darat di bawah proses fluvial berkembang baik. Seanjutnya dataran rawa berkembang dicirikan terhentinya proses pengendapan. Di selatan berkembang lingkungan dataran banjir dan diikuti kegiatan erupsi gunungapi. Ke arah selatan perubahan lingkungan terjadi secara berangsur mulai dataran banjir beralih ke rawa. Secara umum, pembentukan IPP-C di bawah pengaruh kendali iklim menuju semakin minimum.

Geodinamika sedimen Holosen yang terbentuk di daerah penelitian ditandai oleh berbagai fenomena terbentuknya fasies sedimen seperti mekanisme, skala waktu, dan kecepatan perubahan muka laut yang dipengaruhi oleh berbagai faktor (Pling drr., 1992) antara lain perubahan panas atau temperatur, mencairnya es dari peristiwa glasial, suplai air kontinen, dan tektonik yaitu deformasi kerak. Endapan Holosen di bawah dataran pantai modern dapat berfungsi sebagai arsip berharga untuk diuraikan peran perubahan relatif permukaan laut pada arsitektur fasies (Boyd drr., 1992; Blum dan Törnqvist, 2000; Cattaneo dan Steel, 2003; Blum drr., 2013). Suksesi holosen menunjukkan pola fasies yang berbeda dan dapat diprediksi, dan stratigrafinya sudah digunakan secara historis untuk interpretasi tren transgresif-regresif $(\mathrm{T}-\mathrm{R})$ dari sistem pengendapan delta yang lebih tua dan pesisir (Curray dan Moore, 1964; Oomkens, 1970; Frazier, 1974; Demarest dan Kraft, 1987; Suter drr., 1987; Stanley dan Warne, 1994).

Walker dan James (1992), menyatakan bahwa perubahan muka laut, tektonik, iklim, dan evolusi biotik menjadi kendali dinamis pada proses sedimentasi. Pada endapan sungai, faktor yang mempengaruhi mekanisme sedimentasi dibedakan menjadi autogenic (proses internal) dan allogenic (proses eksternal) (Allen dan Allen, 2013 dan Miall, 1992). Menyusut dan meluasnya sistem endapan fluvial adalah bukti berubahnya energi aliran akibat iklim berubah mengikuti tingkat kelembaban (Moechtar, 2019). Kurun waktu Holosen dimulai sejak 10.000 tahun yang lalu, dan 9000 tahun lalu merupakan puncak dari muka laut tertinggi terakhir. Berfluktuasinya muka laut berkaitan erat dengan berubahnya iklim mengikuti siklus Milankovitch. Kondisi iklim secara global pada 20.000 tahun dinyatakan sebagai kondisi iklim kering di mana siklus Milankovitch terakhir menunjukkan sejak awal Holosen di mana posisi kelembapan tinggi menuju kering pada posisi sekarang (Bell \& Walker, 2014).

Daerah Demak selama kala Miosen Akhir - Pliosen Awal telah terjadi 8 (delapan) kali perubahan lingkungan secara fluktuatif dari lingkungan laut dalam menjadi laut dangkal (Jurnaliah drr., 2017). Penurunan muka tanah yang terjadi di dataran Semarang dan Demak selain disebabkan faktor antropogenik juga disebabkan faktor alami (Sarah drr., 2020). Hal tersebut mengindikasikan secara regional terdapat indikasi tektonik. Posisi stratigrafi pada $9730 \pm 240$ tahun yang lalu (Gambar 10) berada pada IPP-A bagian atas yang berarti setara dengan periode awal Holosen. Sehingga IPP-A bagian bawah merupakan lingkungan bagian dari Pleistosen Atas dan akhir Pleistosen Akhir.

Puncak tertinggi muka laut secara global berada pada \pm 9000 tahun yang lalu. Di daerah penelitian posisi tersebut berada pada IPP-A bagian atas. Muka laut ketika itu bukalah sebagai puncak dikarenakan adanya proses pengangkatan di daerah telitian. Oleh karena itu, awal IPP B adalah merupakan proses global muka laut mulai turun (zona regresi).

Terbentuknya IPP-B terkait erat dengan aktifnya tektonik di antaranya turunnya muka laut global diikuti oleh turunnya alas cekungan sehingga muka laut kembali tinggi. Dengan demikian, di kala pembentukan IPP-A dipicu oleh pengangkatan sebaliknya di kala proses IPP-B berlangsung dikendalikan oleh penurunan. Perpaduan 


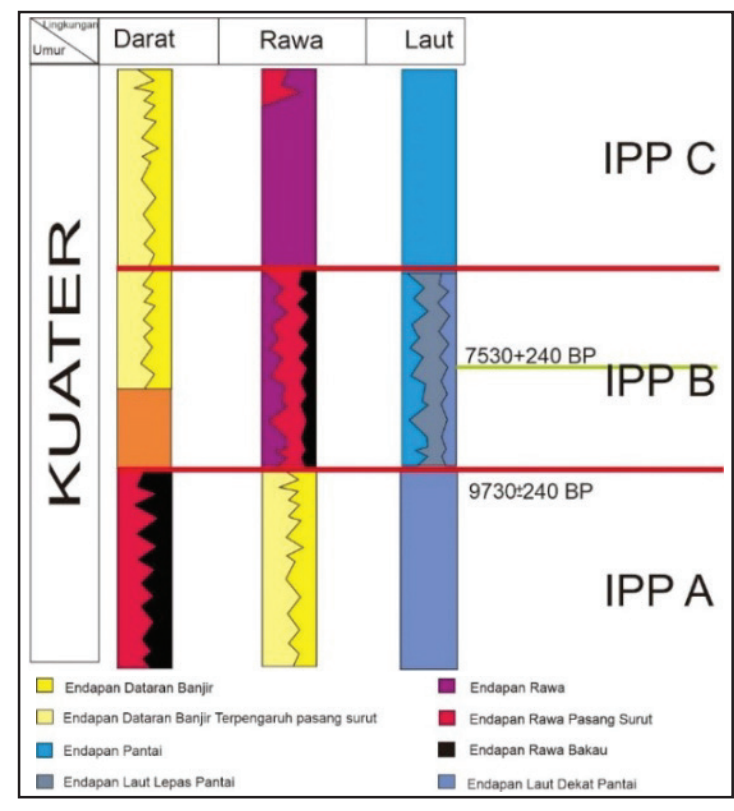

Gambar 8. Kolom Stratigrafi daerah Penelitian dan Hasil Analisis Umur.

antara kecepatan muka laut turun dan tektonik dari rangkaian stratigrafi membuktikan bahwa kecepatan penurunan lebih besar dibandingkan dengan turunnya muka laut yang diperlihatkan oleh bagian tengah IPP-B berumur 7.190 \pm 180 tahun yang lalu atau dengan kata lain muka laut turun tapi masih tinggi akibat besarnya kecepatan penurunan. Kondisi ini terjadi hampir di seluruh lingkungan ketika itu. Proses ini bersifat regional dan proses-proses tersebut terjadi mulai awal hingga akhir Holosen bawah. Gejala turunnaiknya alas cekungan IPP B bagian atas yang membentuk lingkungan rawa pada $7190 \pm 180$ hingga $7530 \pm 240$ tahun yang lalu yang terjadi secara lokal. Hal tersebut mengindikasikan bahwa muka laut naik kembali yang identik dengan tektonik lokal yang peristiwanya berlangsung antara Holosen bawah hingga Holosen tengah. Pada Holosen atas hingga sekarang muka laut turun tanpa dipengaruhi tektonik membentuk IPP-C.

Akhir Pleistosen hingga Holosen bawah ditandai oleh genang laut yang secara global dapat dikorelasikan dalam suasana iklim global adalah lembab (humid). Meski muka laut turun di kala Holosen Bawah, tapi lingkungan laut masih terbentuk hanya di beberapa tempat berkembang lingkungan rawa yang dipengaruhi oleh pasang surut yang ke arah timur terbentuk lingkungan dataran banjir dan dipengaruhi oleh pasang surut. Terbentuknya lingkungan tersebut pada periode Holosen bawah diselang IPP-B bagian bawah yang dipengaruhi oleh iklim di antara optimum menuju minimum dan tingkat kelembapan ketika itu adalah antara basah (humid) hingga agak basah (sub-humid).

Muka laut turun sebagai penciri terbentuknya lingkungan IPP-B bagian atas menghasilkan rawa dari lingkungan fluvial di bawah kendali iklim agak basah. Di saat IPP-C muka laut semakin turun, dominasi lingkungan fluvial semakin menonjol sehingga terbentuknya dataran aluvial sebagaimana yang terlihat kini. Ketika itu bersamaan dengan menurunnya aktivitas alur sungai di bawah pengaruh iklim agak basah hingga kering terbukti dari material alur sungai yang semakin kasar dengan pola alir lurus.

Analisis stratigafi mengungkapkan bahwa ketika suasa iklim optimum diikuti oleh tektonik regional sedangkan disaat kondisi agak basah tektonik lokal berpengaruh. Sebaliknya, erupsi gunungapi yang berlangsung pada Pleistosen akhir dan di bawah pengaruh iklim minimum. Peristiwa tersebut berunglang kembali pada akhir Holosen.

Pemahaman berubahnya iklim dapat ditelusuri pada fasies endapan darat. Oleh karena itu, rekaman berubahnya iklim mengikuti siklus iklim Milankovitch tidaklah lengkap di daerah penelitian. Rekaman jejak berubahnya iklim muncul disaat Pleistosen akhir menuju Holosen bawah (IPP Bawah) dan muncul di beberapa tempat di kala Holosen bawah (IPP B Bawah) dan berkembang secara tidak teratur saat pembentukan IPP-C di kala Holosen atas (Gambar 11) menjelaskan sirkulasi iklim terkait atifitas tektonik. Selain itu, erupsi Gunung Muria berlangsung pada Pleistosen atas di saat muka laut naik dan kondisi iklim yang agak basah. Berubahnya lingkungan sangat terkait dengan proses eksteral seperti turun naiknya muka laut, iklim, tektonik dan erupsi gunungapi. 


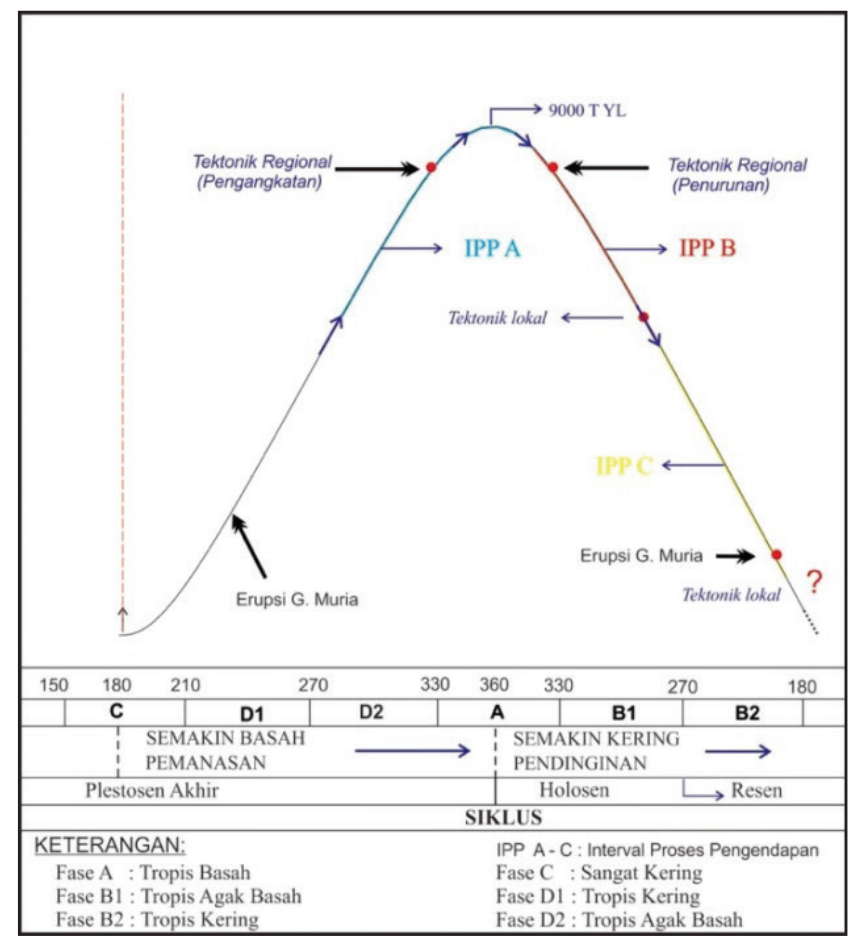

Gambar 8. Kegiatan tektonik dan erupsi Gunung Muria mengikuti sirkulasi Iklim.

\section{KESIMPULAN}

Kontrol berubahnya lingkungan selama Pleistosen Akhir - Holosen di bawah kendali proses eksternal yaitu sirkulasi iklim, berfluktuasinya muka laut, tektonik dan vulkanik. Pada setiap proses tersebut dicirikan oleh karakter sebaran litologi dan fasies baik secara vertikal maupun lateral. Rangkaian startigrafi fasies pengendapannya dapat dikelompokkan menjadi interval proses pengendapan A hingga $\mathrm{C}$. Setiap IPP dapat menjelaskan peristiwa yang dimaksud baik secara global, regional, ataupun lokal. Meluas dan menyusutnya berbagai lingkungan bukan saja terkait oleh energi yang berasal dari laut, aliran dan gravitasi tetapi juga berkaitan erat dengan faktor kegiatan tektonik dan vulkanik. Dari rangkaian peristiwa yang terjadi membuktikan bahwa pada iklim kering menuju basah ditandai oleh kegiatan vulkanik yang menerus pada kondisi kering hingga agak basah. Sebaliknya, ketika muka laut berposisikan maksimum dan iklim optimum disertai oleh kegiatan tektonik regional. Oleh karena itu, didasari siklus dari perioda tersebut dapat ditafsirkan bahwa pada daerah penelitian perubahan lingkungan di kemudian hari menunjukkan kegiatan tektonik semakin merunun di bawah pengaruh iklim kering diakhir pendinginan. Sebaliknya kegiatan vulkanik lebih menonjol dalam suasana iklim kering.

\section{UCAPAN TERIMA KASIH}

Ucapan terimakasih penulis sampaikan kepada Kepala Pusat Survei Geologi yang memberikan kesempatan dalam pengambilan data pada tulisan ini. Penulis juga menyampaikan terimakasih kepada Herman Moechtar atas koreksi, arahan serta tanggapannya selama penulisan ini berlangsung.

\section{DAFTAR PUSTAKA}

Allen, P.A. and Allen, J.R., 2013. Basin analysis: Principles and application to petroleum play assessment. John Wiley \& Sons..

Bell, M. and Walker, M.J., 2014. Late Quaternary environmental change: physical and human perspectives. Routledge. 
Blum, M.D., Martin, J., Milliken, K., Garvin, M., 2013. Paleovalley systems: Insights from Quaternary analogs and experiments. Earth Science Reviews 116, 128-169, doi:10.1016/j.earscirev.2012.09.003

Blum, M.D., Törnqvist, T.E., 2000. Fluvial response to climate and sea level change: A review and look forward. Sedimentology 47, 2-48, doi:10.1046/j.13653091.2000.00008.x

Boyd, R., Dalrymple, R., Zaitlin, B. A., 1992. Classification of clastic coastal depositional environments. Sedimentary Geology 80 , 139-150, doi:10.1016/0037-0738(92)90037$\mathrm{R}$

Cattaneo, A., Steel, R.J., 2003. Transgressive deposits: A review of their variability. EarthScience Reviews 62, 187-228, doi:10.1016/ S0012-8252(02)00134-4

Curray, J.R., Moore, D.G., 1964. Pleistocene deltaic progradation of continental terrace, Costa de Nayarit, Mexico, in: AAPG Memoir, Marine Geology of the Gulf of California, pp. 193-215

Demarest, J.M. II, Kraft, J.C., 1987. Stratigraphic record of Quaternary sea levels: Implications for more ancient strata, In: Nummedal, D., Piikey, O. H., Howard, J. D. (Eds.), Sea-level Fluctuations and Coastal Evolution. SEPM Special Publication 41, pp. 223- 239

Frazier, D.E., 1974. Depositional-episodes: Their relationship to the Quaternary stratigraphic framework in the northwestern portion of the Gulf Basin. Bureau of Economic Geology, The University of Texas at Austin, Geological Circular 74, 1-28

Hidayat, E., 2013. Identifikasi Sesar Aktif di Sepanjang Jalur Kali Garang, Semarang, JSDG. Vol 23. No. 1 Maret 2013. doi:http:// dx.doi.org/10.33332/jgsm.geologi.v23i1.97

Jurnaliah L. , Syrafri I., Sudrajat A., Kapid R., 2017. Perubahan Lingkungan Pengendapan pada Kala Miosen Akhir - Pliosen
Awal Berdasarkan Kumpulan Formanifera Bentonik Kecil pada Lintasan Kali Jragung, Kabupaten Demak, Jawa Tengah, Bulettin of Scientific Contribution Fakultas Teknik Geologi Unpad, 15, 45-52. doi: https://doi.org/10.24198/bsc\%20geology.v15i1.11742.g5601

Miall, A.D., 1992. Alluvial Deposits. In: Walker R.G. and James, N.P. (Eds.), Facies Models response to sea level change. Geological Association of Canada : 119-142.

Moechtar, R.A.T., 2019. Evolusi Cekungan pada Periode Holosen Kaitannya dengan Fluktuasi Muka Air Laut, Tektonik dan Perubahan Iklim di Nabire dan Sekitarnya, Papua. Jurnal Geologi dan Sumberdaya Mineral, 20(4), pp.237-248. doi: http://dx.doi.org/10.33332/ jgsm.geologi.v20i4.484

Mulyono, 1996, Peta Geologi Kuarter Lembar Demak skala $1: 50.000$, Pusat Peneletian dan Pengembangan Geologi, Bandung.

Mulyaningsih, S., Bronto, S., Kusnaedi, A., Simon, I. and Prasetyanto, I.W., 2008. Vulkanisme kompleks Gunung Patiayam di Kecamatan Jekulo, Kabupaten Kudus, Provinsi Jawa Tengah. Indonesian Journal on Geoscience, 3(2), pp.75-88. doi:http://dx.doi. org/10.17014/ijog.vol3no2.20082

Oomkens, E., 1970. Depositional sequences and sand distribution in the postglacial Rhone delta complex, in: Morgan, J.P. (Eds.), Deltaic sedimentation, Modern and Ancient. SEPM Special Publication 15, pp. 198-212.

Perlmutter, M.A. and Matthews, M.D., 1989, April. Global Cyclostratigraphy: effects on the timing of sediment delivery to continental margins relative to sea level. In Chapman Conf. on Long Term Sea Level Changes, Abstr. Progr., Snowbird, Utah, April (pp. 17-20).

Poedjoprajitno, S., Wahyudiono, J., and Cita, A., 2008. Reaktivitas Sesar Kaligarang, Semarang, Jurnal Geologi Indonesia, p-129138. doi: http://dx.doi.org/10.17014/ijog. vol3no3.20082 
Sarah, D., Hutasoit, L.M., Delinom, R.M., and Sadisun, I.A., 2020. Natural Compaction of Semarang-Demak Alluvial Plain and Its Relationship to the Present Land Subsidence, Indonesian Journal on Geoscience, 7 (3), p-273-289. doi:10.17014/ijog.7.3.273-289

Stanley, D.J., Warne, A.G., 1994. Worldwide initiation of Holocene marine deltas by deceleration of sealevel rise. Science 265 , 228-231. doi: 10.1126/science.265.5169.228

Suter, R.J., Berryhill, H.L.Jr., Penland, S., 1987. Late Quaternary sea-level fluctuations and depositional sequences, southwest Louisiana continental shelf, in: Nummedal, D., Pilkey,
O. H., Howard, J.D. (Eds.), Sea-level fluctuation and coastal evolution. SEPM Special Publication 41, pp. 199-219.

Suwarti, T. and Wikarno, S., 1992. Peta Geologi Lembar Kudus, skala 1: 100.000, Jawa. Puslitbang Geologi, Bandung.

Walker, R.G., and James, N,P., 1992. Preface. In: R.G. Walker and N,P. James (eds). Facies Models response to sea level change. Geological Association of Canada

Williams, M.A., Dunkerley, D.L., De Deckker, P., Kershaw, A.P. and Stokes, T.J., 1993. Quaternary environments. In Quaternary environments. Edward Arnold Publishers Ltd. 